\title{
Educational Tourism: What Strategies Needed to Develop It? (A Case Study of Baobab Safari Resort)
}

\author{
Agoes Tinus Lis Indrianto ${ }^{1}$, Rean Mitasari²*, Fidela Perlita Hangga ${ }^{3}$ \\ ${ }^{1,2,3}$ Faculty of Tourism, Universitas Ciputra Surabaya, Indonesia \\ *Corresponding author email: rean.mitasari@ ciputra.ac.id
}

\begin{abstract}
As one of the notable educational tourism destinations, Baobab Safari Resort has attracted huge number of tourists to spend their time being closer with the nature as well as the locals who live surround it. Aside from recreational aspect, the resort offers fruitful benefits in order to give more experiences by staying there for several nights. However, some improvements still need to be taken in order to provide more meaningful values to the visitors after their staying period has finished. Therefore, several strategies in developing the product of educational tourism are needed to give further benefits in which are not only obtained by the management team and the tourists, but also by the communities around the resort. This study aims to identify educational tourism potencies owned by the Baobab Safari Resort Hotel, along with its educational product development strategies. Qualitative method with case study approach was applied to this study and the data was collected through interviews, observation, documentation, and literature study. The result shows that educational tourism in Hotel Baobab Safari Resort can be developed by product innovation, interactive content creation, marketing escalation, and environmental awareness for both the management team and the tourists. Hence, sustainability of the environment and the experience with local communities can be achieved and continuously maintained.
\end{abstract}

Keywords: Educational Tourism, Sustainable Development, Product Development Strategy, Baobab Safari Resort.

\section{INTRODUCTION}

Educational tourism has been around for long time, however, many people have not been familiar with it especially the one offered in the hotel. Several previous studies discussed educational tourism applied by recreational park, museum, tourism village, cultural village, and some other tourist attractions. Yet, the researchers have not found any previous research that specifically discussed educational tourism managed by a hotel. It can be an option for family to go for recreation or holiday as well as educate their children with a concept of learning and playing for merging the experiment, expression, and creation, thus there is a learning process [1].

Baobab Safari Resort is a family hotel with a four starred facility African resort theme that is a business unit of PT Taman safari Indonesia II, in Prigen, Pasuruan. It is not only offering the accommodation for the tourists, but also having its own attractiveness of educational tourism based which offers an experience to get closer to animals and nature. Such experience may not have been perceived by some tourists before. Baobab Safari Resort can be an alternative for domestic or foreign tourists to visit East Java, specifically to Pasuruan regency.

This resort has its potential to reintroduce educational tourism for the public, so this type of tourism can be conserved and enjoyed. Considering the attractiveness potential owned by Baobab Safari Resort and the necessity to innovate the product, the identification of future educational tourism product development strategies is needed to be conducted for developing the 
resort. The paper aims to examine the educational tourism provided in Baobab Safari Resort since the tourists tend to look for new experience during their travel period and it leads to special interest tourism trend. Education plays important role for each individual to add their knowledge, to build their character, and to improve the nation advancement.

\section{LITERATURE REVIEW}

\section{Educational Tourism}

According to Rodger (1998) in [2], educational tourism is a tour that aims to obtain direct learning of the visited tourists' attraction. It can be conducted by developing educational program, and utilizing visual media or visible interpretation Wulandari, 2013, in [3]. Pitana and Diarta (2009), in [4] stated that educational tourism can be a tourism trend in the future due to its attractiveness focused on specific purpose, for instance learning while travelling. Based on the explanation above it can be construed that educational tourism is presented as an option for tourists to learn while traveling. Learning process will be more enjoyable if the tourists have the real learning either from direct obtained experience or from visual media in order to make the learning process becoming more interactive. Educational tourism is a potential type of tourism to be developed, moreover it is supported by various tourist attraction and aimed to those who looked for new experience.

\section{Tourism Product Development Strategy}

According to Craig and Grant (1996) in [5], strategy is a long-term determination of target and objectives done by the company that is needed to achieve both of them. Hamel and Prahalad (1995) in Min [5] stated that strategy is a form of continuous action that is done based on certain perspective of customer expectation in the future. Based on Pearce and Robinson (2008) in Min [5], strategy is a company's "played plan" in order to be able to compete. From the theories mentioned, strategy has an impact on company's future for being able to compete with the existed competitors, obviously by considering customers' purposes and needs. Ansoff matrix is a planning technique to measure the company's growth through products and expansion of networking market [6]. According to [7], there are four tourism product development strategies explained as follows:

(1) Market penetration, adjusting tourism product to attract more number of tourists than before. This strategy has the lowest risk.

(2) Market development, the existed product is used, yet the new market is being pulled as well. This strategy is not too risky since it only adds new targeted market.

(3) Product development, there is a new product addition in the existed market. This strategy is more risky due to tourists' intention that demands innovation of new product.

(4) Product diversification, introducing new product to the new target market. This strategy is highly risky because it needs new product development and new market in which the compatibility has not yet been proved.

\section{METHODS}

Qualitative research approach was applied to this research in which it was conducted in certain setting, existed in the real (natural) life to understand particular phenomena, and was based on "going exploring" concept of a number of cases or a single [8]. This research applied case-study approach in which the subject was able to be studied exhaustively and it involved many factors that enabled the discovery of other findings beyond the problems. The location of this research was Baobab Safari Resort which belonged to a business unit of PT Taman Safari Indonesia II in Prigen, Pasuruan, East Java.

The data used in this research was collected through interview, observation, and library studies. Data resources of this research were consisted of primary and secondary data, in which the primary data was obtained from its original sources and the secondary data was obtained from other people or other institutions [9]. Primary data was derived from field observation and interview, while for secondary data was collected from literature related to educational tourism product development such as books, internet, previous research result, and various related sources. The interview was addressed to purposive sampling participants, those who could provide information related to Baobab Safari Resort, such as: Culture and Tourism Office of Pasuruan Regency, management team of Baobab Safari Resort, product marketing team of Baobab Safari Resort, travel agent, and tourists who had visited to the resort, in order to help the researchers find the answers of the research questions and the data obtained would be more representative [10].

Observation refers to the activity of accurately paying attention to, recording the emergent phenomena, and considering the relation among the aspects of the phenomena Poerwandari,1998 in [8]. The researchers did the observation twice; they were weekdays and weekend visits. Afterwards, the researchers did the documentation to provide visual image of Baobab Safari Resort and to support the description of research object as well as to record the past events Sugiyono, 2007 in [8]. Aside from that, library study was also conducted in this research to undertake development and verification from the systematic data collection and data analysis that related to the examined phenomena Strauss and Corbin,1990 in[8]. In this case, the phenomenon was tourism education 
development in which the example was Baobab Safari Resort.

\section{Data Analysis Technique}

There were three stages conducted by the researchers in analyzing the data obtained in accordance with what had been stated by Miles and [5], namely: 1) Data Reduction, (2) Data Display, and (3) Conclusion drawing / verifying. To test the data validity in this research, triangulation was applied in which there were: (1) theory triangulation to compare the final result of the research with the relevant theories, and (2) triangulation to discover the truth of the information through various sources in obtaining the data [8]. It is also emphasized by Rahardjo (2010) in [8]that each way will yield different proof and data, in which the next will give different perspective regarding to examined phenomena. The source triangulation in this research was conducted by comparing interview data to documentation data, comparing observation data to interview data, and comparing interview data of one informant to the others.

\section{RESULT AND DISCUSSION}

There were four strategies formulated from Ansoff Analysis to develop educational tourism products offered by Baobab Safari Resort: 1) Market penetration, 2) Market development, 3) Product development, and 4) Product diversification.

From market penetration, the resort needs to carefully pay attention to provide additional facilities for the tourists, create the "all-in package", and create the more attractive events with educational contents. The main purposes for those strategies are to attract more visitors and possibly make them to be its repeaters. The provision of more visible signage and information board would ease the tourists in accessing the resort. Movie night of the wildlife in 3D format could increase visitors' interest especially those who came with family or large group. Creating membership program could be an option for those frequently visits the resort. The "all-in package" and the regular one seemed to be more economical and they could be offered during resorts' peak and low seasons. In creating attractive events, the resort might have held it for public in order to save the budget and possibly created more income for the management team. Several events such as batik fashion show with Africa theme, handcrafting, savannah yoga, safari culinary race, African jungle dance, and many others could be held to attract more visitors to spend their time at Baobab Safari Resort.

The market development can be applied by finding new market segment, creating special package for educational institutions, and making use of online and offline media to introduce the products. The aims of this segmentation are to familiarize the existence of Baobab Safari Resort for both domestic and foreign tourists as well as to increase the number of tourists' visits although it needs higher marketing investment. The new targeted markets discussed, for instance, were couples who look for pre-wedding or wedding venue as well as newlyweds. For special package intended to educational institution, it could be in the form of one day tour, outdoor workshop, fieldtrip, and or directly interacted with the animals accompanied by a guide. As for the online and offline media utilization, it would be useful for broader marketing and promotion. Updating the website, managing the ads' appearance as well as the content creation would attract future tourists' attention to visit the resort. Besides, providing the advertisement in the newspaper and toll billboard, and enrolling in famous tourism exhibition enabled the resort to introduce its product for potential buyers.

The next is new product development for the existed market in order to be able to provide high quality product for the tourists. This strategy is quite risky due to the market that always reinforces for the availability of new products to be developed. The first was creating educational tourism package that was not animal based only, but also having cultural element which could be manifested in the presence of animal museum as the means of education for family to gain knowledge about animals. The collection in the museum could be in original or in imitation form and possibly it could be presented virtually to cope with modern trend. Virtual reality (VR) mode could also be developed to provide visual image, knowledge, and life of the animals. The second was offering tourism package for the adults, besides the kids, such as making handcraft or pottery drawing. Those activities were suggested by one of the visitors in order to have something to do while waiting for their children in watching the animals. Furthermore, creating new challenges and adding more tourist attractions would attract more tourists, such as feeding other animals aside from feeding rhino, giraffe, and meerkat. One of informants said that knowing further about wild animals could increase their insight as well as adrenaline.

The last strategy is product diversification. It is applied to introduce the new product to the new targeted market. This strategy is very risky since it needs new product development and new market has not yet been proved whether it is compatible with the new product. However, this strategy can be undertaken because there are opportunity and potency to be developed. Firstly was establishing sustainable tourism that did not damage the environment and invited the tourists to experience living with the locals, for example planting fruits and vegetables that become animals' feed with local farmers. However, 
there should have been a quite wide land for this semiecotourism education product. Secondly was establishing culinary tourism destination in which the ingredients were the area's specialty raw materials. According to one of the informants, Pasuruan is famous for its peculiar durian and coffee. Both of the materials were able to be used to make the food that could become culinary specialties of the area around Baobab Safari Resort or its signature dish.

\section{CONCLUSION}

Based on the presented result and discussion, it can be concluded that possible strategies to be applied for developing the potency of Baobab Safari Resort are market penetration, market development, product development, and diversification. Market penetration strategy can be conducted through increasing the number of tourists visit by providing additional facilities that meet market demands, creating "all-in" package to attract more tourists, and holding attractive events with educational content. Market development strategy aims the new market such as couples, newlyweds, schools and other educational institutions, to develop a market that does not focus on family as the main segment. Aside from adding more new market segment, marketing development through online or offline also needs to be increased. It can be done using online advertising to reach more determined target markets. As for the offline marketing, it can be done through public relations activity for example joining either domestic or foreign related events and or exhibition.

Product development strategy that possibly applied is by creating educational tourism package in which is not animal based only, but also using cultural content for instance handcrafting. The product is able to be developed through more attractive visualization, such as virtual reality (VR) and visual image found in museum nowadays, that can be enjoyed for all ages, including the adults. African culture that becomes the theme of Baobab Safari Resort is possible to be the idea developed. The products that are developed must have the new attractiveness and they should be able to give a challenge and new experience enjoyed by the tourists. The last strategy is product diversification that can be done by establishing sustainable tourism. It should not damage the environment and possibly be able to bring the tourist to mingle with the locals. Packaging the educational tourism that has local content can be an alternative to attract a new market with a new product. With the strategies mentioned, the potencies of Baobab Safari Resort as the destination for educational tourism could be enhanced and is able to compete in globally.

This research, however, still needs some improvements to give more comprehensive studies from various dimensions which have not been covered yet.
Therefore, it is really suggested for further researchers who are interested in product development strategy to continue this research for developing thorough ideas and to become a complement to build more firm strategies used in the industry.

\section{REFERENCES}

[1] P. P. Tabrani, Proses Kreasi - Gambar Anak Proses Belajar. Jakarta: Erlangga, 2014.

[2] N. Maesari, D. Suganda, and C. U. Rakhman, "Pengembangan Wisata Edukasi Berkelanjutan di Museum Geologi Bandung"," J. Tour. Travel Hosp., pp. 17-29, 2018.

[3] L. S. Rachmatin and I. O. Mahagangga, "Wisata Museum Berbasis Edutainment di Jawa Timur Park, Kota Batu, Jawa Timur"," J. Destin. Pariwisata, vol. 4, no. 2, pp. 169-170, 2016.

[4] L. E. Suranny, "Potensi Pengembangan Wisata Edukasi Pada Desa Inovasi Kampung Wayang Kepuhsari Kabupaten Wonogiri"," J. JARLITBANG Pendidik., vol. 3, no. 2, pp. 311-318, 2017.

[5] M. B. Miles, A. M. Huberman, J. Saldana, and Min, Qualitative Data Analysis, A Methods Sourcebook Vol 3". United States of America: Sage Publications. 2014.

[6] R. Wulandari, J. R. Polla, and Novita, "Analisis Peningkatan Daya Saing Ekspor UMKM Cenderamata di Jakarta"," J. Ekon. Vo, vol. 7, no. 1, 2016.

[7] M. A. Morrison, Marketing and Managing Tourism Destinations". 2013.

[8] I. Gunawan, Metode Penelitian Kualitatif: Teori dan Praktik, Ed 1. Cet.4. Jakarta: Bumi Aksara, 2016.

[9] Wagiran, Metodologi Penelitian Pendidikan: Teori dan Implementasi. Yogyakarta: Deepublish CV. Budi Utama, 2013.

[10] I. Hidayat, Metodologi Penelitian". 2017. 